\title{
Article \\ Determination of Genetic Distance, Genome Size and Chromosome Numbers to Support Breeding in Ornamental Lavandula Species
}

\author{
Ewout Van Oost ${ }^{1,2,3, *(D)}$, Leen Leus ${ }^{1}$ D , Bert De Rybel ${ }^{2,3}$ and Katrijn Van Laere ${ }^{1}$ (D) \\ 1 Plant Sciences Unit, Flanders Research Institute for Agricultural, Fisheries and Food Research (ILVO), \\ Caritasstraat 39, 9090 Melle, Belgium; leen.leus@ilvo.vlaanderen.be (L.L.); \\ katrijn.vanlaere@ilvo.vlaanderen.be (K.V.L.) \\ 2 Department of Plant Biotechnology and Bioinformatics, Ghent University, Technologiepark 71, \\ 9052 Ghent, Belgium; bert.derybel@psb.vib-ugent.be \\ 3 VIB Center for Plant Systems Biology, Technologiepark 71, 9052 Ghent, Belgium \\ * Correspondence: ewout.vanoost@ilvo.vlaanderen.be
}

\section{check for}

updates

Citation: Van Oost, E.; Leus, L.; De Rybel, B.; Van Laere, K.

Determination of Genetic Distance,

Genome Size and Chromosome

Numbers to Support Breeding in

Ornamental Lavandula Species.

Agronomy 2021, 11, 2173. https://

doi.org/10.3390/agronomy11112173

Academic Editors:

Agnieszka Marasek-Ciolakowska and Dariusz Sochacki

Received: 16 October 2021

Accepted: 23 October 2021

Published: 28 October 2021

Publisher's Note: MDPI stays neutral with regard to jurisdictional claims in published maps and institutional affiliations.

Copyright: (c) 2021 by the authors. Licensee MDPI, Basel, Switzerland. This article is an open access article distributed under the terms and conditions of the Creative Commons Attribution (CC BY) license (https:/ / creativecommons.org/licenses/by/ $4.0 /)$

\begin{abstract}
Knowledge of phylogenetic relatedness and cytogenetic characteristics can facilitate breeding programs and interspecific hybridization in ornamentals. In this study genetic relationships, genome sizes and chromosome numbers were determined in a collection of 82 lavender genotypes, including 15 hybrids. Amplified Fragment Length Polymorphism (AFLP) marker analysis revealed 5 clusters, corresponding to the sections Lavandula, Stoechas, Dentatae, Pterostoechas and Subnudae. Genome sizes varied between $0.76 \pm 0.02 \mathrm{pg} 2 \mathrm{C}^{-1}$ and $4.80 \pm 0.06 \mathrm{pg} 2 \mathrm{C}^{-1}$ and chromosome numbers ranged from $2 n=22$ to $2 n=100$. Genome sizes of hybrids were intermediate to the progenitors genome sizes. All analyzed hybrid genotypes were characterized by even chromosome numbers, with $2 n=48$ or 50. Using Principal Coordinate Analysis (PCoA) separate hybrid clusters were identified between the progenitor species clusters. Polyploidy and/or aneuploidy was observed in two hybrids genotypes: L. $\times$ intermedia 'Heavenly Angel' $(2 \mathrm{n}=100)$ and $L . \times$ heterophylla 'Big Boy James' $(2 n=66)$. Results obtained in this study can be used to predict cross compatibility among different species, thus enabling targeted breeding towards the creation of new improved Lavandula cultivars.
\end{abstract}

Keywords: lavender; AFLP; phylogeny; polyploidy; C-value; interspecific hybridization

\section{Introduction}

Lavandula is a genus of fragrant flowering evergreen subshrubs or woody-based perennials of the family of Lamiaceae. The genus is composed of 39 species [1]; English lavender (L. angustifolia) and lavandin (L. $\times$ intermedia, a hybrid between L. angustifolia and L. latifolia) are the best known and widely grown for the production of essential oils, for culinary use, and for use as ornamental garden plants [2,3]. Other lavender species such as L. stoechas and L. dentata are restricted to warm and warm-temperate climate regions due to their limited frost resistance [3,4]. Lavandula naturally grows in high mountains, rocky slopes and coastal regions along the Mediterranean, the deserts of North Africa and Arabia, and disturbed habitats in India [1], resulting in significant variation in growth habit and leaf and flower morphology among lavender species. Classifications of Lavandula have been based on morphological characters [3,5,6], leaf flavonoid composition [6], or chromosome numbers [7-9]. More recently, genomic data sets based on internal transcribed spacer (ITS) sequences [6] and phylogenetic markers in the chloroplast DNA (trnK and matK) [1] were used to elucidate the infrageneric relationships in Lavandula. The monophyletic genus [10] is divided in three subgenera: (1) Lavandula with three sections: Lavandula, Stoechas and Dentatae, (2) Fabricia with four sections: Pterostoechas, Subnudae, Chaetostachys and Hasikenses, and (3) Sabaudia with one section: Sabaudia [1,3]. Lavandula is the best known subgenus and includes the economically most valued species, i.e., L. angustifolia, L. latifolia, L. $\times$ intermedia 
and L. stoechas [11]. Chromosome numbers have been studied comprehensively within the Lavandula subgenus, with reports of $2 \mathrm{n}=34,36,42,48,50,54$ or 75 [3,7,8,12,13] for section Lavandula, $2 \mathrm{n}=42,44$ or 45 for section Dentatae and $2 \mathrm{n}=30$ for section Stoechas as reviewed by Upson and Andrews [3]. Upson [6] also determined chromosome numbers in the sections Pterostoechas with $2 \mathrm{n}=22,24$ or 36 , Subnudae with $2 \mathrm{n}=18$ or 36 and Chaetostachys with $2 \mathrm{n}=36$. Moja et al. [1] reported genome sizes of 34 taxa in the genus Lavandula with nuclear DNA amounts ranging from $0.9 \mathrm{pg} 2 \mathrm{C}^{-1}$ in the subgenus Lavandula (section Stoechas) to $3.9 \mathrm{pg} 2 \mathrm{C}^{-1}$ in the subgenus Fabricia (section Pterostoechas). In the subgenus Lavandula, genome sizes were proportional to the chromosome number, with large genome sizes linked to higher chromosome numbers. In contrast, no positive correlation between genome size and chromosome number was found for the subgenus Fabricia.

Breeding in lavender mainly focuses on $L . \times$ intermedia with the aim of improving oil yield and composition of aromatic compounds [14,15]. For ornamental use, improving frost resistance is an important trait in semi-hardy and tender ornamental Lavandula species such as L. stoechas and L. dentata as in temperate climate regions the demand is increasing for cultivars that are both drought tolerant and frost resistant. Interspecific hybridization is an important tool to develop such improved cultivars. Interspecific hybrids have been described within the Lavandula section, including L. $\times$ intermedia (L. angustifolia $\times$ L. latifolia), L. $\times$ losae $($ L. latifolia $\times$ L. lanata $), L . \times$ chaytorae $($ L. lanata $\times$ L. angustifolia $)$. Within the section Stoechas, hybridization between L. stoechas, L. pedunculata and L. viridis is described [3]. Intersectional hybrids are only known between Lavandula and Dentatae, e.g., L. $\times$ heterophylla, $L . \times$ allardii and $L . \times$ ginginsii. These intersectional hybrids are most often products of spontaneous hybridization events and show appealing ornamental traits, e.g., large flower spikes, long flowering period and improved frost resistance, although their frost resistance level is not sufficient for them to thrive in temperate or cool climates [3]. More knowledge about cross compatibility based on the integration of data from genome size measurements, chromosome counting and genetic relatedness studies would facilitate breeding in Lavandula by allowing indicative predictions concerning the success of hybridization and to set up targeted breeding programs (reviewed by Van Huylenbroeck et al. [16]). Several studies, e.g., in Geranium, have shown that a close genetic relatedness as expressed as a Jaccard proximity coefficient, could predict hybridization success [17]. A study on Sarcococca reported that crossing efficiency mostly depends on the ploidy level and $2 \mathrm{C}$ value of the parents, with similar values resulting in a higher crossing efficiency [18]. Further, in Salvia [19], Hydrangea [20] and Rhododendron [21] hybridization success was largely influenced by genetic relatedness.

In the present study, genome sizes, chromosome numbers and genetic distances were determined for a breeding collection containing 82 Lavandula genotypes. A total of 67 nonhybrid and 15 hybrid genotypes were analyzed to identify possible cross combinations and opportunities for interspecific hybridization. Within a breeding context for ornamental lavender, our study focused on hybrids and incorporated mostly commercially available and economically valuable species and cultivars. This (cyto)genetic knowledge will make it possible to predict cross compatibility and identify crossing barriers among Lavandula species. It will also support future breeding programs in lavender, e.g., for improved ornamental traits, enhanced stress resistance, higher oil yield, better oil quality, etc. A wider survey of chromosome numbers in the genus Lavandula is also important to confirm or refute previously reported chromosome numbers [3].

\section{Materials and Methods}

\subsection{Plant Material}

A collection of lavender germplasm comprising 82 Lavandula genotypes (species and cultivars) as collected from nurseries, botanical gardens and seed banks was created at ILVO $\left(51^{\circ} 00^{\prime} \mathrm{N}, 3^{\circ} 48^{\prime} \mathrm{E}\right.$, Melle, Belgium) (Table S1). Three vegetatively propagated plants of each genotype were planted in soil beds in a frost-free greenhouse. Three subgenera (Lavandula, Fabricia, Sabaudia) of the genus Lavandula were represented in this collection, comprising 
13 species. In total 15 hybrid genotypes were collected, including 10 intra-sectional hybrids (L. $\times$ intermedia, $L . \times$ chaytorae and $L . \times$ losae) and 5 intersectional hybrids $(L . \times$ ginginsii, L. $\times$ heterophylla and L. $\times$ allardii). These hybrid genotypes all are commercially available except for L. $\times$ losae (L2), which is a natural hybrid between L. lanata and L. latifolia, and were obtained from the Dutch lavender collection holder Roger Bastin (Kwekerij Bastin, Aalbeek, The Netherlands).

\subsection{Genome Size}

Genome sizes ( $2 \mathrm{C}$ value) of all the genotypes in the Lavandula collection were determined using flow cytometry. A PAS-III flow cytometer (laser $488 \mathrm{~nm}, 25 \mathrm{~mW}$ ) and FloMax ${ }^{\circledR}$ software (Partec, Münster, Germany) was used for most of the samples. For the samples analyzed later during the study a Quantum $P$ flow cytometer equipped with a laser (488 nm; $180 \mathrm{~mW}$ ) and CyPAD software (Quantum Analysis, Münster, Germany) was used. Sample preparation was performed using the CyStain PI kit (Sysmex, Münster, Germany) according to the manufacturer's protocol. Fresh young leaf samples $\left( \pm 0.5 \mathrm{~cm}^{2}\right)$ were chopped with a razorblade together with fresh leaf tissue of the internal standard in $0.4 \mathrm{~mL}$ of extraction buffer according to Galbraith et al. [22]. Additional 1\% (w/w) PVP-10 was added to the extraction buffer. Depending on the genome size of the sample, an internal standard was chosen, either tomato (Solanum lycopersicum 'Stupické polní rané':

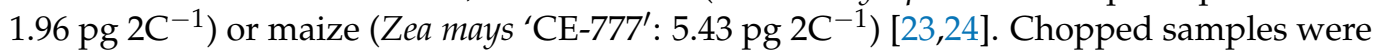
filtrated through a $50 \mu \mathrm{m}$ CellTrics filter (Sysmex, Münster, Germany) and stained in a $1.2 \mathrm{~mL}$ staining buffer with propidium iodide as intercalating DNA stain. Subsequently, the samples were incubated in the dark at $4{ }^{\circ} \mathrm{C}$ for at least $30 \mathrm{~min}$. Three replicate samples were prepared for each genotype on three different days from different plants of the same genotype. On both flow cytometers, histograms were obtained using the FL2 and FL3 detector. At least 3000 particles were analyzed per run. Genome sizes were calculated from the peak positions of the Lavandula sample and the internal reference with known genome size. Mean values and standard deviations were calculated based on the three replicates and two histograms per replicate. Terminology for $2 \mathrm{C}$ values is used as defined by Greilhuber et al. [25].

\subsection{Chromosome Number}

Chromosome numbers were determined in 30 genotypes, which covered all species and hybrid groups of the different sections represented in the germplasm collection. Actively growing root tips $( \pm 1 \mathrm{~cm})$ of 3-week-old cuttings were harvested and incubated in a $10 \mathrm{~mL}$ antimitotic mixture containing $0.1 \%$ colchicine and $0.2 \%$-hydroxyquinoline for $3 \mathrm{~h}$ at $4{ }^{\circ} \mathrm{C}$. Subsequently, the root tips were fixed in 3:1 EtOH:acetic acid for $60 \mathrm{~min}$ at room temperature. Cell suspensions were made by digestion of the root tip tissue using $0.6 \%$ enzyme solution $(0.6 \%$ cellulase, $0.6 \%$ pectolyase, and $0.6 \%$ cytohelicase in $0.1 \mathrm{M}$ citrate buffer $(0.1 \mathrm{M}$ sodium citrate tribasic dihydrate $+0.1 \mathrm{M}$ citric acid) $)$ at $37^{\circ} \mathrm{C}$ for $30 \mathrm{~min}$. Chromosome slides were prepared according to the SteamDrop protocol [26] with a 2:1 and 1:1 EtOH:acetic solution for the first and second fixation step, respectively. Chromosome slides were stained with $1 \%$ DAPI $\left(100 \mathrm{~g} \mathrm{~mL}^{-1}\right)$ diluted in Vectashield mounting medium and analyzed using a fluorescence microscope (AxioImager M2, Carl Zeiss MicroImaging, Zaventem, Belgium) equipped with an Axiocam MRm camera and ZEN software (Carl Zeiss MicroImaging, Zaventem, Belgium) at $1000 \times$ magnification. Image analysis and chromosome counts were carried out on at least five well-spread metaphases of each genotype using the DRAWID software (version 0.26) [27].

\subsection{AFLP}

Amplified Fragment Length Polymorphism (AFLP) was performed on all genotypes in the Lavandula collection. Basil (Ocimum basilicum) was included as an outgroup species. DNA extraction was performed on $20 \mathrm{mg}$ of lyophilized young leaf material using a modified CTAB DNA isolation protocol based on Doyle and Doyle [28]. Extraction buffer 
contained $1 \mathrm{M}$ Tris-HCl, 0.5 M EDTA, $5 \mathrm{M} \mathrm{NaCl}$, 1\% PVP, 2\% CTAB, 0.4\% $\beta$-mercaptoethanol and $100 \mu \mathrm{g} / \mathrm{mL}$ RNase A. Digestion of DNA was executed using five EcoRI and MseI fluorescent-labeled primer combinations and amplification was done with six selective bases: EcoRI-AAC + MseI-CGG, EcoRI-AAC + MseI-CTA, EcoRI-ACA + MseICAT, EcoRI-ACA + MseI-CCA and EcoRI-ACA + MseI-CGG. Fragments were sequenced (Cert-agen $\mathrm{GmbH}$, Rheinbach, Germany) and the ABI Prism ${ }^{\circledR}$ GeneMapper ${ }^{\mathrm{TM}}$ software version 5 (Applied Biosystems, Foster City, CA, USA) was used to analyze AFLP data.

\subsection{Statistical Analysis of AFLP Data}

AFLP fingerprints were analyzed and transformed into a binary data set by scoring all distinct and unambiguous polymorphic bands as 1 (presence of fragment peak) or 0 (absence of fragment peak). Using the vegdist() function in the $\mathrm{R}$ studio software package ( $\mathrm{R}$ Studio, version 3.6.3, 2020), this binary data matrix was converted to a dissimilarity matrix using Euclidean squared distances as a measure for genetic distance between geno-types. The Euclidean squared distance was calculated as Distance Eucl[ij] $=\sqrt{\sum k(x[k i]-x[k j])^{2}}$ where $k$ is the number of bands and $x[k i]$ and $x[k j]$ are the frequencies of occurrence $(0$ or 1$)$ of the $k$ th band in individual $i$ and individual $j$, respectively. The resulting dissimilarity matrix was subjected to cluster analysis using the unweighted pair-group method with the arithmetic averages (UPGMA), as implemented in the hclust() function in R Studio, to create a dendrogram of the 67 genotypes (hybrid genotypes excluded). Branch support values were determined in 1000 bootstrap replicates to support the typology of the dendrogram. Principal Coordinate Analysis (PCoA) was conducted using the function pcoa() in R Studio, taking the dissimilarity matrix as input. A two dimensional plot was constructed to investigate the genetic distance structure among the hybrid and progenitor groups. The R Studio script (Figure S1) to construct the dendrogram and PCoA using the AFLP data are added in Supplementary Materials.

\section{Results}

\subsection{Genetic Distances, Genome Sizes and Chromosome Numbers in the Lavandula} Progenitor Collection

Based on 1496 AFLP markers (Table S3), a phylogenetic tree representing genetic relatedness among 67 non-hybrid lavender genotypes was built (Figure 1). Genome sizes and chromosome numbers of these progenitor genotypes are shown in Figure 1. In the phylogenetic tree, five groups could be distinguished corresponding to the five taxonomic sections in the genus Lavandula: Lavandula, Dentatae, Stoechas, Pterostoechas and Subnudae. Overall, genome sizes ranged from $0.76 \pm 0.02 \mathrm{pg} 2 \mathrm{C}^{-1}$ for L. multifida in section Pterostoechas to $3.14 \pm 0.07 \mathrm{pg} 2 \mathrm{C}^{-1}$ for L. subnuda in section Subnudae (Figures 1 and 2). Chromosome amounts varied between $2 \mathrm{n}=22$ for some species in section Pterostoechas to $2 \mathrm{n}=50$ for some species in section Lavandula. Within section Lavandula, a clustering of the genotypes L. angustifolia, L. latifolia and L. lanata was observed. Within the L. angustifolia cluster, the subspecies L. angustifolia subsp. pyrenaica (L62 and L107) showed less relatedness to the other L. angustifolia genotypes. L. stoechas 'Van Gogh's Babies' (L104) and L. latifolia 'Muffet's Children' (L105) both clustered with the L. angustifolia genotypes (Figure 1) and were characterized by a similar genome size $\left(2.15 \pm 0.06 \mathrm{pg} 2 \mathrm{C}^{-1}\right.$ and $2.11 \pm 0.07 \mathrm{pg} 2 \mathrm{C}^{-1}$ respectively), and chromosome number $(2 n=48)$ (Figure 1$)$. Both genotypes were thus considered to be incorrectly named (Table S2). In section Lavandula, L. lanata genotypes had

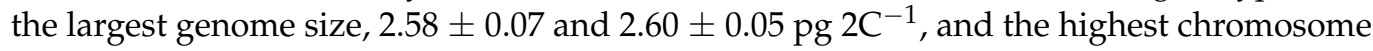
number of $2 \mathrm{n}=50$ (Figure 3B). L. latifolia genotypes had a genome size between $2.48 \pm 0.05$ and $2.59 \pm 0.07 \mathrm{pg} 2 \mathrm{C}^{-1}$ (Figures 1 and 2 ) and $2 \mathrm{n}=50$ chromosomes, while L. angustifolia genotypes were characterized by a smaller genome size, between $2.02 \pm 0.09$ and $2.25 \pm 0.08$ pg $2 \mathrm{C}^{-1}$ (Figures 1 and 2) and two chromosomes fewer, $2 \mathrm{n}=48$ (Figure 3A). Section Stoechas comprised two closely related species, i.e., L. stoechas and L. pedunculata, as could be distinguished in the phylogenetic tree (Figure 1). Based on their clustering, L. stoechas 'Papillon' (L74) and L. stoechas (L128) are to be considered as genotypes of the 
species L. pedunculata (Table S2). Genome sizes in section Stoechas were very similar among all members of the species with a value between $0.84 \pm 0.03$ and $0.89 \pm 0.02 \mathrm{pg} 2 \mathrm{C}^{-1}$ in 11 analyzed L. stoechas genotypes. A genome size between $0.90 \pm 0.02$ and $0.93 \pm 0.02 \mathrm{pg} 2 \mathrm{C}^{-1}$ was determined in L. pedunculata genotypes (L15, L34, L74, L128) (Figures 1 and 2). Chromosomes were counted for two L. stoechas genotypes (L28 and L27), which both had $2 \mathrm{n}=28$ chromosomes (Figure 3C). L. pedunculata (L15) was characterized by a chromosome number of $2 \mathrm{n}=30$ (Figure 3D). Within section Dentatae, comprising only the species L. dentata, the three genotypes found in western Morocco, i.e., L. dentata 'Cap Rhir' (L10), L. dentata 'Adrar Mkorn' (L7), and L. dentata 'Iminifri' (L6), clustered together (Figure 1). Section Dentatae was characterized by a chromosome number of $2 \mathrm{n}=44$ (Figure 3E) and a genome

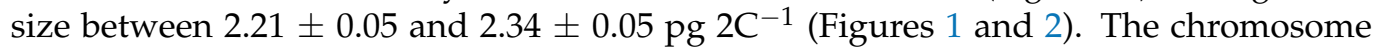
number and genome size in L. dentata were very similar to those of L. antineae (L118) from the Pterostoechas section. Two sections of the subgenus Fabricia were present in the germplasm collection: Pterostoechas and Subnudae. Based on the phylogenetic tree, genome sizes and chromosome numbers (Figure 1), section Pterostoechas could be divided into two groups. The first group comprises two L. canariensis genotypes (L94 and L119), L. rotundifolia (L121) and L. multifida (L96, L126 and L12). This group of genotypes was characterized by a chromosome number of $2 \mathrm{n}=22$ (Figure $3 \mathrm{G}-\mathrm{I}$ ), with genome sizes varying between $0.76 \pm 0.02 \mathrm{pg} 2 \mathrm{C}^{-1}$ in L. multifida to $1.62 \pm 0.04 \mathrm{pg} 2 \mathrm{C}^{-1}$ in L. rotundifolia. The second group contains L. antineae (L118) and L. pubescens (L99, L115, L116 and L117). Genome sizes and chromosome numbers were higher for this group of genotypes. L. antineae was

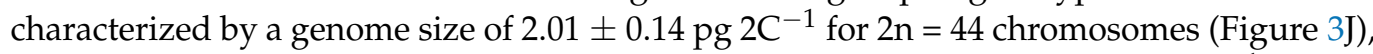
while genome size range in L. pubescens was $2.27 \pm 0.04$ to $2.44 \pm 0.05 \mathrm{pg} 2 \mathrm{C}^{-1}$ with a chromosome number $2 n=40$ (Figure $3 \mathrm{~F}$ ). Noteworthy is that in L. pubescens and L. canariensis, both small and large chromosomes were observed in one cell, possibly indicating a hybrid nature of these species (Figure 3F,G). The species name L. maroccana (L95) clustered in between two other L. multifida genotypes (L96 and L129) and should be considered as a L. multifida genotype (Figure 1, Table S2). For section Subnudae, only one representative could be collected. This genotype is distantly related to the other sections and had the largest genome size $\left(3.14 \pm 0.07 \mathrm{pg} 2 \mathrm{C}^{-1}\right)$ in the collection. The plant died before the chromosome number could be determined.

\subsection{Genetic Distances, Genome Sizes and Chromosome Numbers in Lavandula Hybrids}

To visualize the genetic relationship of hybrid genotypes with their putative progenitors, AFLP data of the 67 progenitor genotypes and 15 hybrid lavender genotypes were included in a Principal Coordinate Analysis (PCoA). The obtained two-dimensional PCoA plot was composed of two factors explaining $17.1 \%$ and $11.1 \%$ of genetic variation (Figure 4). This PCoA largely reflects the clustering in the phylogenetic tree for the progenitor genotypes. Only the one representative of section Subnudae, L. subnuda (L114), is shown as closely related to the species in section Pterostoechas, while in the phylogenetic tree it was recognized as distinct section (Figure 1). The different hybrid groups were clearly distinguishable on the PCoA plot, as they clustered apart from their putative progenitor species group (Figure 4). 


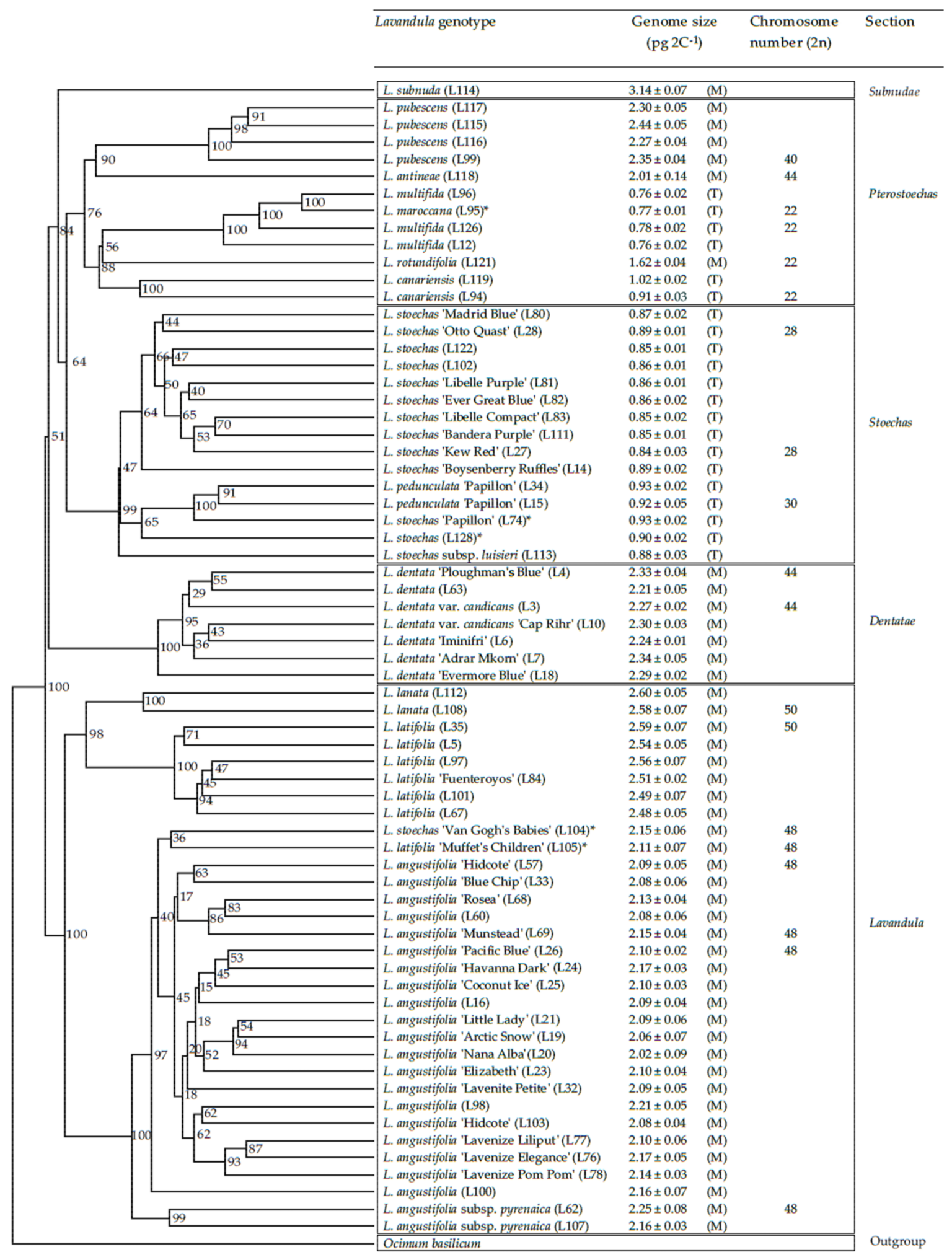

Figure 1. Phylogenetic tree of 67 Lavandula progenitor genotypes (species and commercial cultivars) clustered in 5 taxonomical groups. The dendrogram was created after conversion of AFLP data in a distance matrix and application of an average clustering method (UPGMA) in R Studio (R Studio version 3.6.3., 2020). Bootstrap values $(n=1000)$ are to the right side of the branching node. Genome size and chromosome number measured in our study were added to the respective genotypes. The standard deviation on genome size measurements and plant species used as internal standard are men-tioned next to the $2 \mathrm{C}$ values (Zea mays (M), Solanum lycopersicum (T)). Putative misnamed genotypes were marked with an asterisk $(*)($ Table S2). 


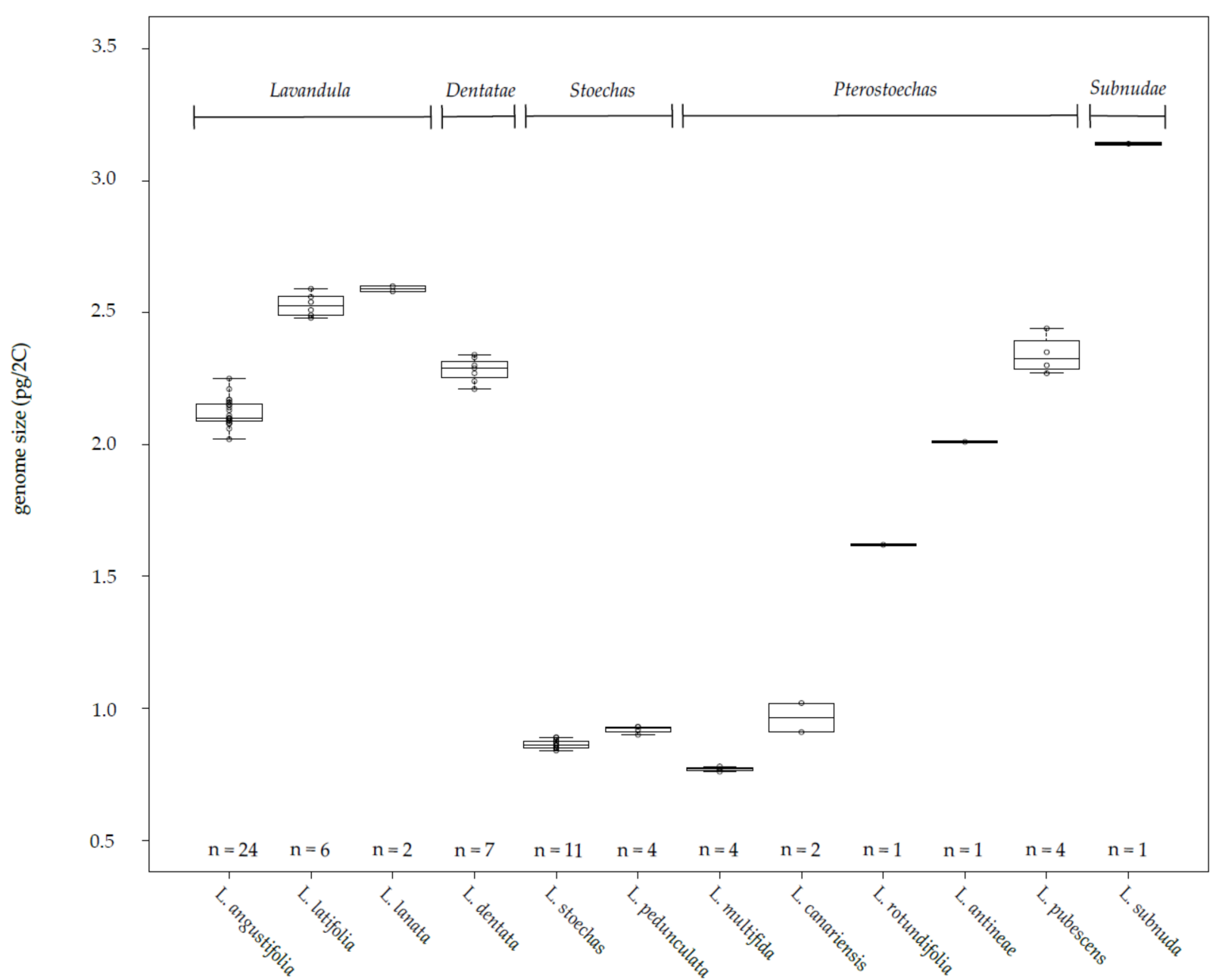

Figure 2. Boxplot of genome sizes (2C values) for 12 Lavandula species. Individual data points and number of genotypes analyzed per species $(n=)$ are shown. The median genome size value for every species is represented by the line in every box. Sections of the genus Lavandula are shown above the boxplots.

Genome size also served to confirm the hybrid character of some hybrid groups. Within the Lavandula section, $L . \times$ intermedia genotypes originate from crosses between $L$. angustifolia and L. latifolia, $L . \times$ chaytorae genotypes from crosses between $L$. angustifolia and L. lanata genotypes, and $L . \times$ losae from crosses between L. latifolia and L. lanata genotypes. L. lanata, L. latifolia and L. angustifolia species formed separate clusters within the Lavandula section. The $L . \times$ intermedia, $L . \times$ chaytorae and $L . \times$ losae genotypes were separated in distinctive hybrid clusters located between the progenitor species groups (Figure 4). The obtained genome sizes of $2.28 \pm 0.07$ to $2.37 \pm 0.08 \mathrm{pg} \mathrm{2C}^{-1}$ of L. $\times$ intermedia genotypes were intermediate compared to the progenitors genome sizes which varied from $2.02 \pm 0.09$ to $2.25 \pm 0.08 \mathrm{pg} 2 \mathrm{C}^{-1}$ in L. angustifolia and from $2.48 \pm 0.05$ to $2.59 \pm 0.07 \mathrm{pg}$ $2 \mathrm{C}^{-1}$ in L. latifolia (Table 1). The chromosome number observed in this hybrid group was $2 \mathrm{n}=50$ (Table 1 ). In addition, one polyploid L. $\times$ intermedia genotype was detected: $L . \times$ intermedia 'Heavenly Angel' (L30), $2 \mathrm{n}=100$ (Figure 3L). The genome size of $L$. $\times$ intermedia

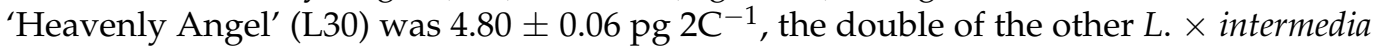
genotypes, thus indicating tetraploidy for this genotype. Only L. $\times$ intermedia 'Silver' (L73) clustered within the L. angustifolia group (Figure 4). 


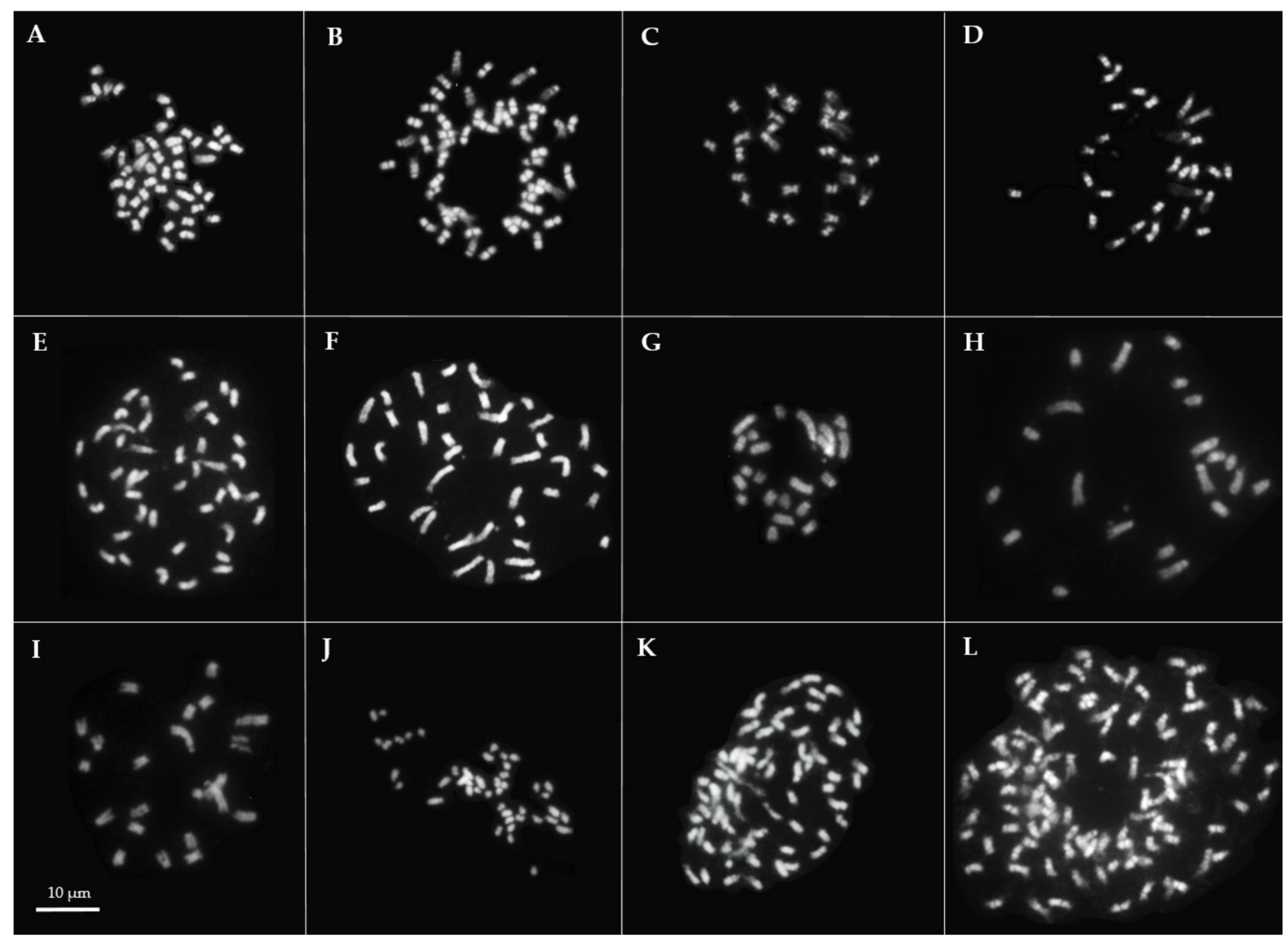

Figure 3. Chromosome counts of Lavandula genotypes: L. angustifolia 'Hidcote' (L57), $2 \mathrm{n}=48$ (A); L. lanata (L108), $2 \mathrm{n}=50$ (B); L. stoechas 'Otto Quast' (L28), 2n = 28 (C); L. pedunculata 'Papillon' (L15), 2n = 30 (D); L. dentata (L4), 2n = 44 (E); L. pubescens (L99), $2 \mathrm{n}=40(\mathbf{F}) ;$ L. canariensis (L94), $2 \mathrm{n}=22(\mathbf{G}) ;$ L. rotundifolia (L121), $2 \mathrm{n}=22(\mathbf{H}) ;$ L. multifida (L126), $2 \mathrm{n}=22(\mathbf{I}) ;$ L. antineae (L118), 2n = 44 (J); L. $\times$ heterophylla 'Big Boy James' (L13), 2n = $66(K) ;$ L. $\times$ intermedia 'Heavenly Angel' (L30), 2n = 100 (L). Scale bar $=10 \mu \mathrm{m}$.

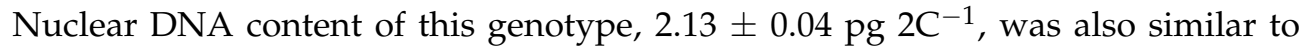
L. angustifolia. Therefore, $L . \times$ intermedia 'Silver' was considered to be misnamed (Table S2). For $L . \times$ chaytorae and $L . \times$ losae, a chromosome number of $2 \mathrm{n}=50$ was measured for both hybrid groups, corresponding to the progenitors' chromosome numbers (Table 1). For $L . \times$ chaytorae genotypes (L8 and L22), the obtained genome sizes of $2.33 \pm 0.09$ and $2.30 \pm 0.06 \mathrm{pg} 2 \mathrm{C}^{-1}$ were intermediate compared to the progenitors' genome sizes which

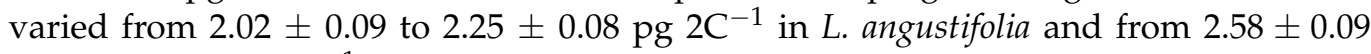
to $2.60 \pm 0.05 \mathrm{pg} 2 \mathrm{C}^{-1}$ in L. lanata. In contrast, for $L . \times$ losae, with a genome size of $2.55 \pm 0.03 \mathrm{pg} 2 \mathrm{C}^{-1}$, the difference in genome sizes compared to the progenitors' geno-

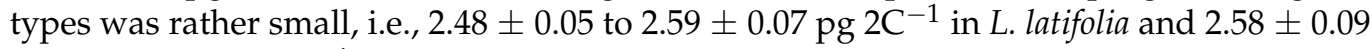
to $2.60 \pm 0.05 \mathrm{pg} 2 \mathrm{C}^{-1}$ in L. lanata. Intersectional hybrids between L. latifolia and L. dentata (L. $\times$ heterophylla and L. $\times$ allardii) and L. lanata and L. dentata $(L . \times$ ginginsii) clustered together between the groups formed by the progenitor species. Genome sizes of $L . \times$ ginginsii, $2.43 \pm 0.04 \mathrm{pg} 2 \mathrm{C}^{-1}, \mathrm{~L} . \times$ allardii, $2.49 \pm 0.05 \mathrm{pg} 2 \mathrm{C}^{-1}$ and $L . \times$ heterophylla, $2.42 \pm 0.05$ pg $2 \mathrm{C}^{-1}$ and $2.43 \pm 0.05 \mathrm{pg} 2 \mathrm{C}^{-1}$ were intermediate to genome sizes of the progenitor groups (Table 1). A chromosome number of $2 \mathrm{n}=48$ was measured in L. $\times$ ginginsii, L. $\times$ heterophylla and L. $\times$ allardii (L9, L17 and L11). The higher chromosome number of L. $\times$ heterophylla 'Big Boy James' (L13), $2 \mathrm{n}=66$ (Figure 3K), was in accordance to the larger nuclear DNA content, $3.50 \pm 0.06 \mathrm{pg} 2 \mathrm{C}^{-1}$, measured in this genotype. 


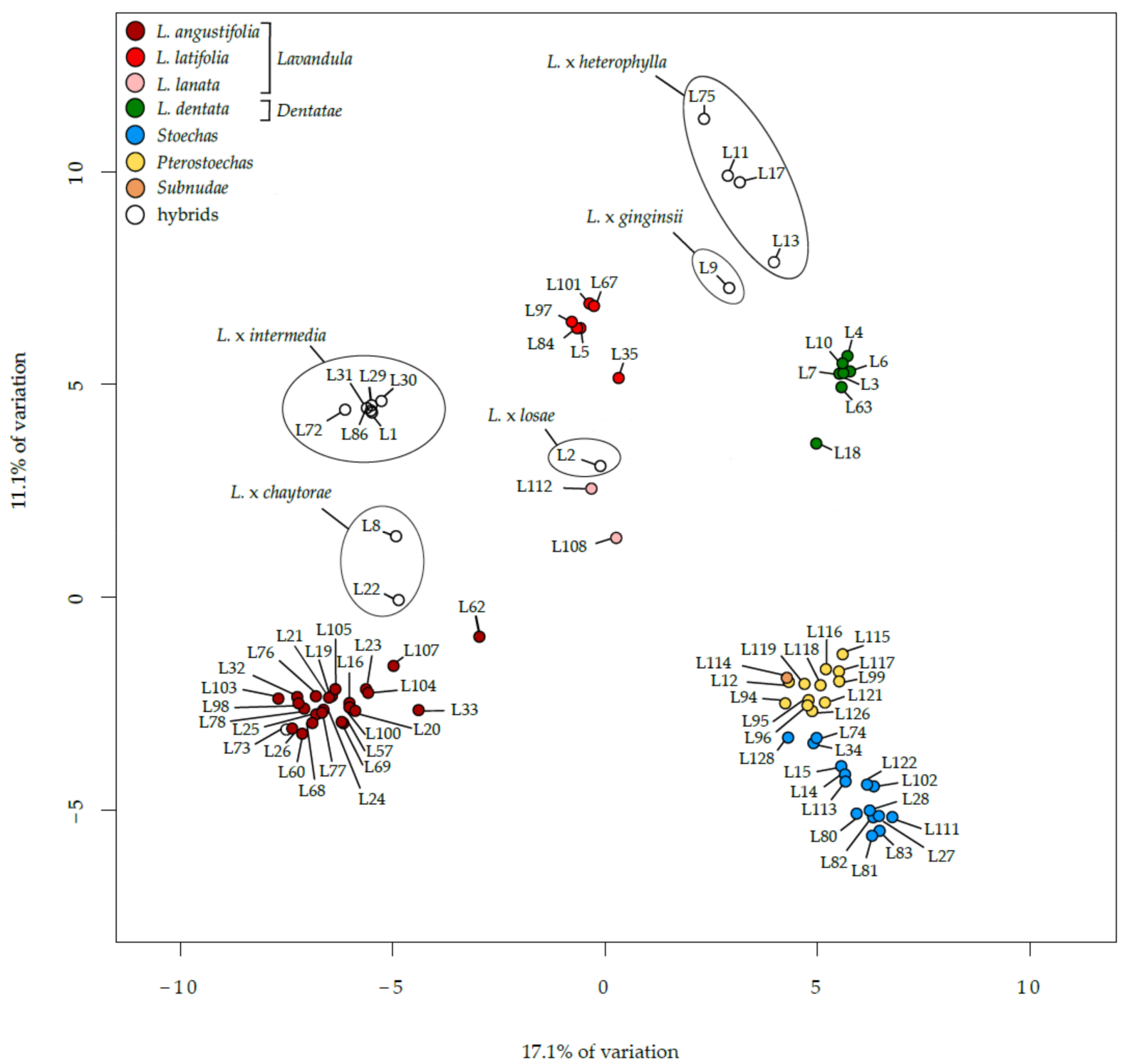

Figure 4. Principal Coordinate Analysis (PCoA) plot based on AFLP data of 82 genotypes of Lavandula. Different sections or species of the genus are indicated with different colors. The X-and Y-axis comprise $17.1 \%$ and $11.1 \%$ of the variation, respectively. Hybrid groups are encircled. 
Table 1. Inter- and intrasectional hybrids together with progenitor background and the hybrids' respective chromosome number and genome size. Progenitor chromosome numbers mentioned are numbers found in literature and own counts. Chromosome numbers in bold indicate the values both found in our study and in literature. The genome sizes of the progenitors are given as a range based on genome size measurements from our study in 28 L. angustifolia, 6 L. latifolia, 7 L. dentata and 2 L. lanata genotypes. The standard deviation on genome size measurements and plant species used as internal standard are mentioned next to the $2 \mathrm{C}$ values (Zea mays $(\mathrm{M})$, Solanum lycopersicum $(\mathrm{T})$ ). n.a. = not analyzed.

\begin{tabular}{|c|c|c|c|c|c|}
\hline Progenitors & $\begin{array}{l}\text { Progenitor } \\
\text { Chromosome } \\
\text { Number (2n) }\end{array}$ & $\begin{array}{c}\text { Progenitor } \\
\text { Genome Size }\left(\mathrm{pg} 2 \mathrm{C}^{-1}\right)\end{array}$ & Hybrid Genotype (Code) & $\begin{array}{l}\text { Hybrid } \\
\text { Chromosome } \\
\text { Number (2n) }\end{array}$ & 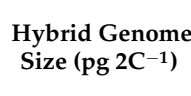 \\
\hline $\begin{array}{l}\text { L. angustifolia } \times \\
\text { L. latifolia }\end{array}$ & $\begin{array}{c}42, \mathbf{4 8}, 50,54 \\
48, \mathbf{5 0}, 54\end{array}$ & $\begin{array}{l}2.02 \pm 0.09-2.25 \pm 0.08 \\
2.48 \pm 0.05-2.59 \pm 0.07\end{array}$ & $\begin{array}{c}\text { L. } \times \text { intermedia 'Silver' (L73) a } \\
\text { L. } \times \text { intermedia 'Old English Group' (L29) } \\
\text { L. } \times \text { intermedia 'Futura' (L86) } \\
\text { L. } \times \text { intermedia 'Nizza' (L1) } \\
\text { L. } \times \text { intermedia 'Edelweiss' (L31) } \\
\text { L. } \times \text { intermedia 'Dutch' (L72) } \\
\text { L. } \times \text { intermedia 'Heavenly Angel' (L30) }\end{array}$ & $\begin{array}{c}50 \\
50 \\
\text { n.a. } \\
50 \\
\text { n.a. } \\
\text { n.a. } \\
100\end{array}$ & $\begin{array}{l}2.13 \pm 0.04(\mathrm{M}) \\
2.36 \pm 0.09(\mathrm{M}) \\
2.28 \pm 0.07(\mathrm{M}) \\
2.32 \pm 0.06(\mathrm{M}) \\
2.37 \pm 0.08(\mathrm{M}) \\
2.35 \pm 0.04(\mathrm{M}) \\
4.80 \pm 0.06(\mathrm{~T})\end{array}$ \\
\hline $\begin{array}{l}\text { L. angustifolia } \times \\
\quad \text { L. lanata }\end{array}$ & $\begin{array}{l}42, \mathbf{4 8}, 50,54 \\
\mathbf{5 0}, 54\end{array}$ & $\begin{array}{l}2.02 \pm 0.09-2.25 \pm 0.08 \\
2.58 \pm 0.07-2.60 \pm 0.05\end{array}$ & $\begin{array}{c}\text { L. } \times \text { chaytorae 'Gorgeous' (L8) } \\
\text { L. } \times \text { chaytorae 'Richard Gray' (L22) }\end{array}$ & $\begin{array}{l}50 \\
50\end{array}$ & $\begin{array}{l}2.33 \pm 0.09(\mathrm{M}) \\
2.30 \pm 0.06(\mathrm{M})\end{array}$ \\
\hline $\begin{array}{l}\text { L. latifolia } \times \\
\text { L. lanata }\end{array}$ & $\begin{array}{l}48, \mathbf{5 0}, 54 \\
\mathbf{5 0}, 54\end{array}$ & $\begin{array}{l}2.48 \pm 0.05-2.59 \pm 0.07 \\
2.58 \pm 0.07-2.60 \pm 0.05\end{array}$ & L. $\times$ losae (L2) & 50 & $2.55 \pm 0.03(\mathrm{M})$ \\
\hline $\begin{array}{l}\text { L. dentata } \times \\
\text { L. lanata }\end{array}$ & $\begin{array}{l}\mathbf{4 4}, 42,45 \\
\mathbf{5 0}, 54\end{array}$ & $\begin{array}{l}2.21 \pm 0.05-2.34 \pm 0.05 \\
2.58 \pm 0.07-2.60 \pm 0.05\end{array}$ & L. $\times$ ginginsii ‘Goodwin Creek Grey' (L9) & 48 & $2.43 \pm 0.04(\mathrm{M})$ \\
\hline $\begin{array}{l}\text { L. dentata } \times \\
\text { L. latifolia }\end{array}$ & $\begin{array}{l}\mathbf{4 4}, 42,45 \\
48, \mathbf{5 0}, 54\end{array}$ & $\begin{array}{l}2.21 \pm 0.05-2.34 \pm 0.05 \\
2.48 \pm 0.05-2.59 \pm 0.07\end{array}$ & $\begin{array}{c}\text { L. } \times \text { allardii 'African Pride' (L11) } \\
\text { L. } \times \text { heterophylla 'Devantville Cuche' (L17) } \\
\text { L. } \times \text { heterophylla 'Meerlo' (L75) } \\
\text { L. } \times \text { heterophylla 'Big Boy James' (L13) }\end{array}$ & $\begin{array}{c}48 \\
48 \\
\text { n.a. } \\
66\end{array}$ & $\begin{array}{l}2.49 \pm 0.05(\mathrm{M}) \\
2.42 \pm 0.05(\mathrm{M}) \\
2.43 \pm 0.05(\mathrm{M}) \\
3.50 \pm 0.06(\mathrm{M})\end{array}$ \\
\hline
\end{tabular}

${ }^{a}$ L. $\times$ intermedia 'Silver' is considered to be a misnamed cultivar and presumably belonging to the species L. angustifolia (Table S2).

\section{Discussion}

The present study of genetic relationships and cytogenetic characteristics of Lavandula was performed to facilitate interspecific breeding programs. The genetic relationships in a lavender collection were determined by constructing a phylogenetic tree and PCoA graph. Genome sizes and chromosome numbers were determined to elucidate cytogenetic differences. The phylogenetic analysis showed clustering of all genotypes in 5 distinct sections, in accordance to the classification proposed by Upson [6] and Moja et al. [1], which were based on ITS sequence data and chloroplast DNA data, respectively. Our work differed from those studies in some ways. Upson [6] recognized two major groups in the ITS-based phylogeny, with section Lavandula, Dentatae and Stoechas in one group, and section Pterostoechas and Subnudae in the second group. In our study, section Stoechas appeared to be closely related to sections Pterostoechas and Subnudae (Figures 1 and 4). Our study included mostly commercially available and economically valuable species and cultivars, rather than compiling a taxonomic complete collection as was the case in other studies (e.g., Upson [6] and Moja et al. [1]).

Although the chromosomes were small and difficult to count, the chromosome number of 30 genotypes could be determined. A total of 9 different chromosome numbers, from $2 \mathrm{n}=22$ to $2 \mathrm{n}=100$, were reported in this study, confirming the already reported large variation in chromosome number in the genus Lavandula (reviewed by Upson and Andrews [3]). Consequently, considerable variation in genome size was observed in the

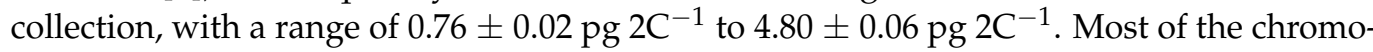
some numbers in our study were in accordance with literature, even though reports on chromosome numbers did not always agree, e.g., for L. angustifolia $2 \mathrm{n}=34,36,42,48,50$ and 54 are reported $[3,7,8,12,13]$. In this study a chromosome number of 48 was identified in all four L. angustifolia genotypes analyzed. A careful interpretation of previously reported chromosome numbers is needed, as the counting of chromosomes in the genus Lavandula is complicated due to the presence of small chromosomes and the prevalence of oil droplets in the cytosol. As an example, the chromosome count of $2 n=36$ for L. angustifolia is controversial and generally cited as erroneous [3]. In our study, a chromosome number of $2 \mathrm{n}=28$ was found for both analyzed L. stoechas cultivars, which was in contrast to 
other publications that reported a chromosome number of $2 n=30$ in section Stoechas [3]. These different chromosome numbers could be the result of the frequent hybridization observed in the section among the species L. stoechas, L. pedunculata and L. viridis [3]. As such, the progenitors of L. stoechas 'Otto Quast' (L28) and L. stoechas 'Kew Red' (L27) are unknown but it is not unlikely that two or even all three species of section Stoechas were involved, as is true for most other commercial L. stoechas cultivars [3]. Within section Pterostoechas, which comprises lavender species from the subtropics and (semi-)arid regions of Africa and Southeast Asia, 2n = 22 chromosomes were found for L. multifida, L. rotundifolia and L. canariensis. These confirm findings in literature [3]. In contrast, L. pubescens and L. antineae, also from section Pterostoechas, were found to have higher chromosome numbers ( $2 \mathrm{n}=40$ and 44 , respectively) and larger genome sizes. This is not in agreement with Upson [6] who reported $2 \mathrm{n}=36$ for L. pubescens. Moreover, our study was the first to report a chromosome number for L. antineae. Still within section Pterostoechas, hybridization is commonly observed, involving L. buchii, L. canariensis, L. rotundifolia, L. coronopifolia, L. multifida and L. maroccana [3]. It is likely that ancestral hybridization events could explain the chromosome differences found in our study and other reports. In addition, the presence of both small and large chromosomes in L. pubescens and L. canariensis emphasizes the possibility of a hybrid background.

The frequently observed hybridization events within sections, e.g., Stoechas, Pterostoechas, and Lavandula, shows the opportunities for interspecific breeding and the creation of durable and appealing ornamental lavender cultivars. Several hybrids are already described. Despite small differences in chromosome numbers $(2 n=48$ or $2 n=50)$ and genome sizes ( $2.02 \pm 0.09$ to $2.60 \pm 0.05$ pg 2C $\mathrm{C}^{-1}$ ) (Figure 2) between L. angustifolia, L. lanata and L. latifolia, the three species in section Lavandula are cross compatible and result in viable offspring, i.e., L. $\times$ intermedia, $L . \times$ losae and $L . \times$ chaytorae. Chromosome numbers and genome sizes of these hybrids were in line with those found in progenitor species groups, although the exact progenitor genotypes of the hybrids are unknown. The genome size of the hybrid genotypes corresponded to the average of genome sizes of the progenitor species groups, as was especially clear for $L . \times$ intermedia and $L . \times$ chaytorae. Consequently, when genotypes differing in genome sizes are crossed, genome size measurements can be used as an efficient tool to distinguish and select hybrid progeny at an early stage of the breeding process. Based on our data, indications can also be found for successful intersectional cross combinations. Chromosome numbers and genome sizes in section Dentatae were comparable to section Lavandula (Figure 2), indicating a close genetic relationship between these two sections, which is also punctuated by the existence of intersectional hybrids between these two sections. L. $\times$ ginginsii resulted from a cross between L. lanata and L. dentata, and $L . \times$ heterophylla and $L . \times$ allardii are hybrid offspring from L. latifolia and L. dentata. These hybrids were lucky finds in botanical or collectors' gardens. Intersectional hybrids have not been reported in the wild. In addition to (cyto)-genetic relatedness, successful hybridization in the wild is affected by other factors, such as synchronized flowering time and overlapping natural distributions of the progenitor species. When spatial and geographical barriers are removed, e.g., in botanical gardens, hybridization can take place. No hybrids have been reported between L. angustifolia and L. dentata; this hybrid progeny would be particularly interesting as it would combine the frost hardiness of L. angustifolia and the appealing flowering characteristics of L. dentata. Given that L. angustifolia is closely related to L. lanata and L. latifolia and that the latter two species are cross-compatible with L. dentata, it can be hypothesized that hybridization between L. angustifolia and L. dentata would also succeed. As such, new economically valuable cultivars of ornamental lavender could be created in targeted breeding programs. Intersectional hybrids between Lavandula and Stoechas have not been described yet, but probably would not be successful due to large genetic distances and significant differences in genome size and chromosome number, leading to crossing barriers. Chromosome numbers of intra- and intersectional hybrids have not been reported, except for $L . \times$ intermedia with $2 n=51$ or 50 [6,29]. Upson and Andrews [3] suggested that the odd chromosome number of $2 n=51$ for L. $\times$ intermedia 
could be the primal cause for the general sterility observed in hybrid lavender. In contrast, our study only reported even chromosome numbers for hybrid lavender. L. $\times$ intermedia, $L . \times$ losae and $L . \times$ chaytorae were all characterized by $2 n=50$ chromosomes, and L. $\times$ ginginsii, $L . \times$ allardii and $L . \times$ heterophylla by $2 n=48$ chromosomes.

In our study, two polyploid genotypes were detected, $L . \times$ heterophylla 'Big Boy James' $(2 n=66)$ and $L . \times$ intermedia 'Heavenly Angel' $(2 n=100)$. The chromosome number of $2 \mathrm{n}=100$ measured in L. $\times$ intermedia 'Heavenly Angel' can be due to the involvement of unreduced gametes, resulting in a doubled number of chromosomes when compared to the other $L . \times$ intermedia genotypes. In $L . \times$ heterophylla 'Big Boy James' the chromosome count of $2 n=66$ suggests a more complex background. Vinot and Bouscary [30] reported a fertile L. $\times$ intermedia with $2 \mathrm{n}=100$ chromosomes growing in a field of sterile L. $\times$ intermedia plants. The doubling of chromosomes in this hybrid was believed to account for its (restored) fertility [29]. However, the hybrid genotype L. $\times$ chaytorae 'Gorgeous' (L8) $(2 n=50)$ is also reported to be fertile [3]. This was confirmed in our study, as seeds were harvested on an open pollinated L. $\times$ chaytorae 'Gorgeous' (L8) on the trial field of ILVO (Melle, Belgium, 2021) (data not shown). A study on the fertility of hybrid genotypes, including pollen viability and compatibility of pollen and stigma, would provide important information on the influence of chromosome numbers and polyploidy on the fertility of lavender hybrids. This study has been initiated at our research institute (ILVO, Melle, Belgium) and will be a scope for future research. Upson and Andrews [3] stated that polyploidy is recognized to be a major and active evolutionary force in the genus Lavandula at all taxonomic levels, and the identification of polyploid genotypes in our study, detected among hybrids, confirms this. The occurrence of polyploid hybrid genotypes also offers opportunities for lavender breeding since polyploidy in ornamentals is known to result in altered appealing characteristics compared to their diploid counterparts, e.g., larger flowers, longer flowering period, and altered stress resistance [31,32].

By combining AFLP data, genome sizes and chromosome numbers, six presumably misnamed genotypes were identified. However, these conclusions should be interpreted with caution as taxonomic classification was not included in the scope nor the capacity of the present study. Commercial lavender can be propagated by either cuttings or seeds, which influences the genetic composition of a cultivar. For example, the considerable genetic distance between two L. angustifolia 'Hidcote' (L57 and L103) genotypes in the phylogenetic tree can possibly be attributed to differences in propagation technique.

\section{Conclusions}

Interspecific hybridization is frequently observed within the genus Lavandula, but mostly occurs among species within one section. As our data suggest, similar cytogenetic traits as genome size, chromosome number, and the close genetic relationships of species within a section allow for hybridization success, e.g., interspecific hybridization of species within section Lavandula or section Stoechas. Intersectional hybrids are only observed between sections Lavandula and Dentatae, i.e., hybrid offspring of L. dentata and L. latifolia or L. lanata. Our study revealed a close resemblance in cytogenetic traits between the sections Lavandula and Dentatae. Given the cross-compatibility observed between section Lavandula and section Dentatae, it can be hypothesized that interspecific hybridization between L. angustifolia and L. dentata would also succeed, but further breeding efforts are needed. On the other hand, considerable genetic distances and substantial differences in genome size or chromosome number assumedly impose crossing barriers, e.g., between sections Lavandula and Stoechas. The analysis of genetic relationships and cytogenetic characteristics in this study proved to be a valuable tool to reliably characterize starting material and assess the opportunities and possibilities for a breeding program in lavender involving interspecific hybridization. 
Supplementary Materials: The following are available online at https: / www.mdpi.com/article/ 10.3390/agronomy11112173/s1, Figure S1: Computer code (R Studio script) for constructing a dendrogram (1) and PCoA analysis (2); Table S1: Overview of the collected Lavandula genotypes, the assigned code and acqui-sition source with IPEN-code or serial number in parentheses when available; Table S2: Overview of the assumed misnamed genotypes in the collection and their presumably correct names; Table S3: AFLP data.

Author Contributions: Conceptualization, E.V.O., L.L. and K.V.L.; methodology, E.V.O., L.L. and K.V.L.; data curation, E.V.O.; formal analysis, E.V.O.; investigation, E.V.O.; writing-original draft preparation, E.V.O.; writing-review and editing, E.V.O., L.L., B.D.R. and K.V.L.; visualization, E.V.O.; supervision, L.L., K.V.L., B.D.R. All authors have read and agreed to the published version of the manuscript.

Funding: This research received no external funding.

Data Availability Statement: The data presented in this study are available on request from the corresponding author.

Acknowledgments: The authors wish to sincerely thank Katrien Liebaut for DNA extraction, AFLP analysis and chromosome counting, Magali Losschaert and Margo De Smet for chromosome counting, Michiel Carron, Nancy Mergan and Paulien Vekeman for genome size measurements. Special thanks go to Roger Dobbelaere and Rina Vanhaecke for their skillful and excellent management of the greenhouse plants, and to Miriam Levenson for English-language editing. We would also like to thank BEST-Select CVBA (Melle, Belgium) for valuable input.

Conflicts of Interest: The authors declare no conflict of interest.

\section{References}

1. Moja, S.; Guitton, Y.; Nicolè, F.; Legendre, L.; Pasquier, B.; Upson, T.; Jullien, F. Genome size and plastid trnK-matK markers give new insights into the evolutionary history of the genus Lavandula L. Plant Biosyst. 2016, 150, 1216-1224. [CrossRef]

2. Lis-Balchin, M. Lavender: The Genus Lavandula; CRC Press: London, UK, 2002; p. 296. [CrossRef]

3. Upson, T.; Andrews, S. The Genus Lavandula; Royal Botanic Gardens Kew: Richmond, UK, 2004; p. 442.

4. McNaughton, V. Lavender: The Grower's Guide; Blooming Books: Caringbah, Australia, 2000; p. 180.

5. Wunderlich, R. Ein Vorschlag zu einer natürlichen Gliederung der Labiaten auf Grund der Pollenkörner, der Samenentwicklung und des reifen Samens. Oesterreichische Bot. Z. 1967, 114, 383-483. [CrossRef]

6. Upson, T. Systematics of the Genus Lavandula L. (Lamiaceae). Ph.D. Thesis, University of Reading, Reading, UK, 1997.

7. Garcia, J. Contribuição para o estudo cário-sistemático do género Lavandula L. Bol. Soc. Broteriana 1942, 13, $183-193$.

8. Buyukli, M. On karyotype and polyploid series in Lavandula L. Citol. Genet. 1970, 4, 268-274.

9. Suárez-Cervera, M.; Seoane-Camba, J. Taxonomía numérica de algunas especies de Lavandula L., basada en caracteres morfológicos, cariológicos y palinológicos. An. Jard. Bot. Madr. 1986, 42, 395-409.

10. Paton, A.; Springate, D.; Suddee, S.; Otieno, D.; Grayer, R.; Harley, M.; Willis, F.; Simmonds, M.; Powell, M.; Savolainen, V. Phylogeny and evolution of basils and allies (Ocimeae, Labiatae) based on three plastid DNA regions. Mol. Phylogenet. Evol. 2004, 31, 277-299. [CrossRef]

11. Ez Zoubi, Y.; Bousta, D.; Farah, A. A Phytopharmacological review of a Mediterranean plant: Lavandula stoechas L. Clin. Phytosci. 2020, 6, 9. [CrossRef]

12. Darlington, C.; Wylie, A. Chromosome Atlas of Flowering Plants; George Allen and Unwin Ltd.: London, UK, $1955 ;$ p. 519.

13. Rice, A.; Glick, L.; Abadi, S.; Einhorn, M.; Kopelman, N.; Salman-Minkov, A.; Mayzel, J.; Chay, O.; Mayrose, I. The Chromosome Counts Database (CCDB)-A community resource of plant chromosome numbers. New Phytol. 2015, 206, 19-26. [CrossRef] [PubMed]

14. Stanev, S.; Zagorcheva, T.; Atanassov, I. Lavender cultivation in Bulgaria-21st century developments, breeding challenges and opportunities. Bulg. J. Agric. Sci. 2016, 22, 584-590.

15. Urwin, N. Lavender Breeding for Commercial Yield@. Comb. Proc. Int. Plant Propagator Soc. 2008, 58, 78-84.

16. Van Huylenbroeck, J.; Eeckhaut, T.; Leus, L.; Van Laere, K.; Dhooghe, E. Bridging the gap: Tools for interspecific and intergeneric hybridization in ornamentals. In Proceedings of the XXVI International Eucarpia Symposium Section Ornamentals: Editing Novelty, Erfurt, Germany, 1-4 September 2019; Volume 1283, pp. 161-168. [CrossRef]

17. Akbarzadeh, M.; Van Laere, K.; Leus, L.; De Riek, J.; Van Huylenbroeck, J.; Werbrouck, S.P.O.; Dhooghe, E. Can knowledge of genetic distances, genome sizes and chromosome numbers support breeding programs in hardy geraniums? Genes 2021, 12, 730. [CrossRef] [PubMed]

18. Denaeghel, H.; Van Laere, K.; Leus, L.; Van Huylenbroeck, J.; Van Labeke, M.C. Interspecific hybridization in Sarcococca supported by analysis of ploidy level, genome size and genetic relationships. Euphytica 2017, 213, 149. [CrossRef] 
19. Tychonievich, J.; Warner, R. Interspecific crossability of selected Salvia species and potential use for crop improvement. J. Am. Soc. Hortic. Sci. 2011, 136, 41-47. [CrossRef]

20. Kardos, J.; Robacker, C.; Dirr, M.; Rinehart, T. Production and verification of Hydrangea macrophylla $\times$ H. angustipetala hybrids. Hortic. Sci. 2009, 44, 1534-1537. [CrossRef]

21. Handa, T.; Kita, K.; Wongsawad, P.; Kurashige, Y.; Yukawa, T. Molecular phylogeny-assisted breeding of ornamentals. J. Crop Improv. 2006, 17, 51-68. [CrossRef]

22. Galbraith, D.; Harkins, K.; Maddox, J.; Ayres, N.; Sharma, D.; Firoozabady, E. Rapid flow cytometric analysis of the cell cycle in intact plant tissues. Science 1983, 220, 1049-1051. [CrossRef]

23. Doležel, J.; Sgorbati, S.; Lucretti, S. Comparison of three DNA fluorochromes for flow cytometric estimation of nuclear DNA content in plants. Physiol. Plant. 1992, 85, 625-631. [CrossRef]

24. Lysak, M.; Dolezel, J. Estimation of nuclear DNA content in Sesleria (Poaceae). Caryologia 1998, 51, 123-132. [CrossRef]

25. Greilhuber, J.; Dolezel, J.; Lysák, M.; Bennett, M. The origin, evolution and proposed stabilization of the terms 'genome size' and 'C-value' to describe nuclear DNA contents. Ann. Bot. 2005, 95, 255-260. [CrossRef]

26. Kirov, I.; Divashuk, M.; Van Laere, K.; Soloviev, A.; Khrustaleva, L. An easy "SteamDrop" method for high quality plant chromosome preparation. Mol. Cytogenet. 2014, 7, 21. [CrossRef] [PubMed]

27. Kirov, I.; Khrustaleva, L.; Van Laere, K.; Soloviev, A.; Meeus, S.; Romanov, D.; Fesenko, I. DRAWID: User-friendly java software for chromosome measurements and idiogram drawing. Comp. Cytogenet. 2017, 11, 747-757. [CrossRef]

28. Doyle, J.; Doyle, J. A rapid DNA isolation procedure for small quantities of fresh leaf tissue. Phytochem. Bull. 1987, 19, 11-15.

29. Urwin, N.; Horsnell, J.; Moon, T. Generation and characterisation of colchicine-induced autotetraploid Lavandula angustifolia. Euphytica 2007, 156, 257-266. [CrossRef]

30. Vinot, M.; Bouscary, A. Etudes sur la Lavande. VI. Les hybrides. Recherches 1971, 18, $29-44$.

31. Sattler, M.; Carvalho, C.; Clarindo, W. The polyploidy and its key role in plant breeding. Planta 2016, 243, 281-296. [CrossRef] [PubMed]

32. Van Laere, K.; França, S.; Vansteenkiste, H.; Van Huylenbroeck, J.; Steppe, K.; Van Labeke, M.C. Influence of ploidy level on morphology, growth and drought susceptibility in Spathiphyllum wallisii. Acta Physiol. Plant. 2011, 33, 1149-1156. [CrossRef] 